\title{
EFFECT OF HUMIC ACID AND SULFUR FERTILIZER LEVELS ON SOME PHYSIOLOGICAL TRAITS OF MAIZE (ZEA MAYS L.) ON CALCAREOUS SOIL
}

\author{
MARUF, M. T. - MAM-RASUL, G. A. \\ Department of Natural Resources, College of Agricultural Engineering Sciences, Sulaimani, Iraq \\ (e-mails/phones: muhamad.maruf@univsul.edu.iq/+964-770-146-8930, \\ ghafwr.mamrasul@univsul.edu.iq/+964-770-156-3130) \\ (Received $3^{\text {rd }}$ Jun 2019; accepted $2^{\text {nd }}$ Sep 2019)
}

\begin{abstract}
The field experiment was conducted at two locations, Qlyasan and Kanipanka in Sulaimani governorate, Iraq. The main aim of this research is, to evaluate the impact of adding various levels of Humic Acid and Sulfur rates on maize yield and yield components. Experimental treatments have been organized and a factorial experiment was laid out in a complete randomized block design with three replicates. The treatments included four levels of humic acid, and four levels of sulfur incorporated into the soil. The results showed that the effect was significant at $(\mathrm{P}<0.05)$ on the reproductive growth criteria of a maize plant. The number of kernels per ear, the weight of 100 kernels $(\mathrm{g})$, kernel yield (ton $\mathrm{ha}^{-1}$ ), biological yield (ton $\mathrm{ha}^{-1}$ ), harvest index and relative yield maize plant from both of locations. While the results showed that the humic acid and sulfur application significantly affected of the number of kernels per raw from Kanipanka and of the ear diameter $(\mathrm{cm})$ from Qlyasan, it did not affect the number of kernels per raw from Qlyasan location and by the ear diameter $(\mathrm{cm})$ from Kanipanka location.
\end{abstract}

Keywords: kernels, biological yield, relative yield

\section{Introduction}

Maize (Zea mays L.) is the third most important cereal crop in the world after wheat and rice. Maize is a miracle crop called "Queen of Cereals", is grown in more than 130 countries and it belongs to the family of Gramineae (Poaceae), (Shah et al., 2009) and tribe Maydeae, all varieties of the maize belong to a single species which is Zea mays (Sikandar et al., 2007). Iraqi Kurdistan region as a semi-arid region, there is an increasing interest for field crop production and recommended farmers to grow grain crops and vegetables.

An increasing the number of human population continuously increases their demands for food and energy, which require to incorporate the new areas in agricultural as well as increase the crop yield-per unit of area with healthy quality with good nutritional or healthy quality. Generally, the average yield of maize is greater than (4 ton ha ${ }^{-1}$ ) (Farnhamet al., 2003). The maize cultivation in Iraq in the last decade increased, because of its importance as previously mentioned, its cultivation focused in the south of Iraq in Wasit, Meesan and AL-Qadeseya governorates, with only (3500 ha) during 1998. In 2014, the cultivated area with maize in Iraq increased to (299500 ha) with average production (4166.5 $\mathrm{kg} \mathrm{ha}^{-1}$ ), Central Statistical Organization of Iraq (2014). The maize cultivation in the Kurdistan region-Iraq has got more attention in last year's. The cultivated area in Kurdistan region roughly is about (1824 ha) with average production about $\left(5138 \mathrm{~kg} \mathrm{ha}^{-1}\right),(\mathrm{KRG}, 2014)$. In the last decade, the maize production increased about (40\%) reaching (840) million tons in the world in 2011 (FAO, 2009).

In terms of nutrient acquisition efficiency by the plant, Maize may have different strategies in response to nutrient deficiency. In addition to that the strategy of Maize cultivation is recently had been introduced to the Kurdistan Iraqi region, and every year 
new high-yielding maize varieties are continually being evolved and introduced by the breeder to be grown by farmers in the area. However, the properties such as economic, quality and grain yield potential of this new Maize not fully aware by the farmers (Hogir, 2016).

Therefore, intensive efforts of the researchers were focused on how to maximize the productivity of this crop through highly nutrient efficient, especially for humic acids and sulfur fertilizers.

Humic acid (HA) is a naturally occurring polymericheterocyclic organic compound with carboxylic $\left(\mathrm{COOH}^{-}\right)$, phenolic $\left(\mathrm{OH}^{-}\right)$, alcoholic and carbonyl fractions extracted from various sources such as lignite, peat, coal, farmyard manure, coirpith besides natural persistence in soil (Sharif et al., 2002). Humic acids is not only found in soil, plants, peat, natural water, rivers, sea sediments, and other chemically and biologically transformed materials but also extracted from lignite, oxidized bituminous coal, leonardite and gyttja (Karaca et al., 2006).

The mechanism of humic acid activity in promoting plant growth is not completely known, but several explanations have been proposed by some researchers such as increasing cell membrane permeability, oxygen uptake, respiration and photosynthesis, phosphate uptake, and root cell elongation (Turkmen et al., 2004). Addition of HA to soil increases the rate of absorption of ions on root surfaces and their penetration into the cells of the plant tissue. Plants show more active metabolism and increased respiratory activity, which are attributed to the intervention of the quinine groups of HA (Atefe and Ali, 2012). The physicochemical and molecular structure and the mechanism of its stimulating effect on various crops and soil conditions have been envisaged by various workers (Singh and Agrawal, 2010; Cordeiro et al., 2011).

The sulfur (S) dynamics and its availability are less studied than other nutrients, even though $S$ is an essential nutrient for crops production (Rheinheimer et al., 2007). Most soil sources of sulfur are in organic matter and are therefore concentrated in the topsoil or plow layer. Elemental sulfur and other forms as found in soil organic matter and some fertilizers are not available to crops. They must be converted to sulfate $\left(\mathrm{SO}_{4}{ }^{2-}\right)$ form to become available to crops. This $\mathrm{SO}_{4}{ }^{2-}$ is available to crops when the roots reach this area of the soil. Sulfur is a part of the amino acids cystine, cysteine and methionine and is therefore required for protein formation and hence plant growth. Sulfur is also present in plant oils and is involved in enzyme activation. Many common crop plants contain approximately the same amount of sulfur as they do of phosphorus (Scherer, 2001). Sulfur is a by-product of the oil industries, despite this, it is found in a comparatively large amount in Iraq in the fields of Mashraq, which has a production capacity of one million tons annually, so the addition of sulfur has become a standard method for a number of researchers as a means of managing nutrients in the soil.

This study aims to investigate the influence of humic acids and sulfur individually or mixing on yield characteristics of maize growing under calcareous soil condition.

\section{Review of literature}

Humic acid (HA) is a naturally occurring polymericheterocyclic organic compound with carboxylic $\left(\mathrm{COOH}^{-}\right)$, phenolic $\left(\mathrm{OH}^{-}\right)$, alcoholic and carbonyl fractions extracted from various sources such as lignite, peat, coal, farmyard manure, coirpith besides natural persistence in soil (Sharif et al., 2002). Humic acids are not only found in soil, plants, peat, natural water, rivers, sea sediments, and other chemically and biologically 
transformed materials but also extracted from lignite, oxidized bituminous coal, leonardite and gyttja (Karaca et al., 2006). The humic substances are distributed in soil, peat, coal, many upland streams, dystrophic lakes, and ocean water (Stevenson, 1994).

Humic acids are technically not a fertilizer, although in some walks people do consider it. Humic acids are an effective agent to use as a complement to synthetic or organic fertilizers. In many instances, regular humic acids use will reduce the need for fertilization due to the soil and plant ability to make better use of it. In some instances, fertilization can be eliminated entirely if sufficient organic material is present and the soil can become self-sustaining through microbial processes and humus production.

To promote efficient plant absorption of nutrients and reduce environmental pollution, some chemical molecules have been studied (Ertani et al., 2011) these compounds are defined as bio-stimulants such as humic substances.

In many studies, humic and fulvic acids preparations were reported to increase the uptake of mineral elements (Mackowiak et al., 2001), to promote the root length (Canellas et al., 2002), and to increase the fresh and dry weights of crop plants (Chen et al., 2004).

The use of humic acids has been on the increased in last year's. Improvement of soil conditions and establishing equilibrium among plant nutrients are also important for soil productivity and plant production. Humic acids and organically improvement of soil increased the yields of some field crops in several studies (Ulukan, 2008).

The sulfur (S) dynamics and its availability are less studied than other nutrients, even though $\mathrm{S}$ is an essential nutrient for crops production (Rheinheimer et al., 2007). In a general overview of the element we can at first, describe sulfur as a solid. It is a pale yellow non-metallic, brittle element and is widely distributed in close proximity to hot springs and volcanoes and is also found in many minerals and ores. Sulfur is one of (16) essential elements for crop growth. Although sulfur is considered as a secondary nutrient, it is often called the fourth major nutrient ranking just below nitrogen, phosphorus, and potassium. It is also an essential nutrient for plant growth and development as it is a part of major metabolic compounds such as amino acids (methionine and cysteine), glutathione, proteins, and sulpho-lipids (Duke and Reisenauer, 1986). Most soil sources of sulfur are in organic matter and are therefore concentrated in the topsoil or plow layer. Elemental sulfur and other forms as found in soil organic matter and some fertilizers are not available to crops. They must be converted to sulfate $\left(\mathrm{SO}_{4}{ }^{2-}\right)$ form to become available to crops. This $\mathrm{SO}_{4}{ }^{2-}$ is available to crops when the roots reach this area of the soil. Sulfur is a part of the amino acids cysteine, cysteine and methionine and is therefore required for protein formation and hence plant growth. Sulfur is also present in plant oils and is involved in enzyme activation. Many common crop plants contain approximately the same amount of sulfur as they do of phosphorus (Scherer, 2001).

Maize dry weight increased as elemental sulfur rate increased, after which there was a sharp decrease in dry maize weight. This was mainly due to the significant increase in soil Mn and Zn availability (Karimizarchi and Aminuddin, 2015) and uptake by maize as demonstrated by Karimizarchi et al. (2014). Scherer (2001) provides an overview of soil sulfur transformations describes the diverse forms of organic sulfur in soil and outlines the processes linked to sulfur mineralization that release $\mathrm{SO}_{4}{ }^{2-}$. Most studies on sulfur mineralization have involved laboratory experimentation. There is limited information on the rates of sulfur mineralization in field soils. 
The maize is the major source of starch in the worldwide. It can be fed to stock as green chop, dry forage, silage or grain. Various fractions of milling processes, also it can be used as animal feed. Furthermore, maize uses in nonfood making products such as drugs, paper goods, paints, textiles (cloths) and ceramics (Jones, 2003).

An increasing the number of human population continuously increases their demands for food and energy, which require to incorporate the new areas in agricultural as well as increase the crop yieldper unit of area with healthy quality with good nutritional or healthy quality. Among all grain crops, the maize has the highest yield per hectare (Du Plessis, 2003). Generally, the average yield of maize is greater than (4 ton ha ${ }^{-1}$ ) (Farnham et al., 2003).

The maize cultivation in Iraq in the last decade increased, because of its importance as previously mentioned, its cultivation focused in the south of Iraq in Wasit, Meesan and AL-Qadeseya governorates, with only (3500 ha) during 1998. In 2014, the cultivated area with maize in Iraq increased to (299500 ha) with average production (4166.5 $\left.\mathrm{kg} \mathrm{ha}^{-1}\right)$, Central Statistical Organization of Iraq (2014). The maize cultivation in the Kurdistan region-Iraq has got more attention in last year's. The cultivated area in Kurdistan region roughly is about (1824 ha) with average production about (5138 kg ha-1), (Ministry of Agriculture and Irrigation, Kurdistan regional government, Iraq, 2014). In the last decade maize production increased about (40\%) reaching (840) million tons in the world in 2011 (FAOSTAT, 2013).

Therefore, intensive efforts of the researchers were focused on how to maximize the productivity of this crop through highly nutrient efficient, especially for humic acids and sulfur fertilizers.

Calcareous soil is a soil that has high levels of both calcium carbonate and magnesium that reduce acidity in the soil and covers more than one-third of the cultivable surface land in the world. Calcareous soil can have differing levels of sand, silt or clay as well as coarse to fine texture. This soil type typically maintains a moderate to high alkalinity (Pasricha et al., 2001).

Calcareous soils are common and widely spreader not only in arid and semiarid regions but also is formed in humid and per humid regions, due to the relatively low leaching and the nature of the weathered parent material such as limestone, shells (Sandstone) or calcareous glacial tills (Brady and Weil, 2002) and relatively young parent material which subjected to slight weathering process (Pal et al., 2000).

Lalljee and Facknath (2001) and Alloway (2008) found that micronutrients solubility in calcareous soils is extremely low because the $\mathrm{pH}$ value of these soils is high, which reduces nutrient absorption by plants, finally increases plant requirements to these nutrients. In addition to this, high rate of fertilization with P-fertilizers prompts micronutrients deficiencies in plants. Therefore, micronutrients content in plant dry matter and crops yield will reduce (Salimpour et al., 2010).

\section{Materials and methods}

To assess the impact of humic acid and sulfur incorporated into the soil on yield and yield constituents of maize (Zea mays L.) cv. Gloria, grown under calcareous soil, the experiment was conducted at two different locations. The first one at Qlyasan Agricultural Research Farm (45.3581 E, $35.5767 \mathrm{~N} 757 \mathrm{~m}$ above sea level) and the second one at Kanipanka Agricultural Research Farm (45.7161 E, 35.3822 N 578 m above sea level) in Sulaimani governorate, Iraq as shown in (Fig. 1) during spring 
growing season of $\left(10^{\text {th }}\right.$ and $11^{\text {th }}$ April 2017 to $29^{\text {th }}$ and $27^{\text {th }}$ July 2017) respectively. The experiment includes four levels of humic acid as humate potassium (Humic 85\%), obtained from AFICO factory in Jordan, $\left(\mathrm{H}_{0}=0, \mathrm{H}_{1}=25, \mathrm{H}_{2}=50\right.$ and $\mathrm{H}_{3}=100 \mathrm{~kg} \mathrm{HA}$ $\mathrm{ha}^{-1}$ ) and four levels of sulfur, obtained from LAWA factory in Sulaimani-Iraq, as agricultural sulfur, which contained $99 \% \quad \mathrm{~S} \quad\left(\mathrm{~S}_{0}=0, \mathrm{~S}_{1}=500, \mathrm{~S}_{2}=1000\right.$ and $\mathrm{S}_{3}=2000 \mathrm{~kg} \mathrm{~S} \mathrm{ha}{ }^{-1}$ ) were incorporated into the soil in deep by $5 \mathrm{~cm}$ at sowing time. Average of the rainfall and air temperature climatic data of the experiment field locations (Kanipanka and Qlyasan) in 2017 showing in Tables 1 and 2.

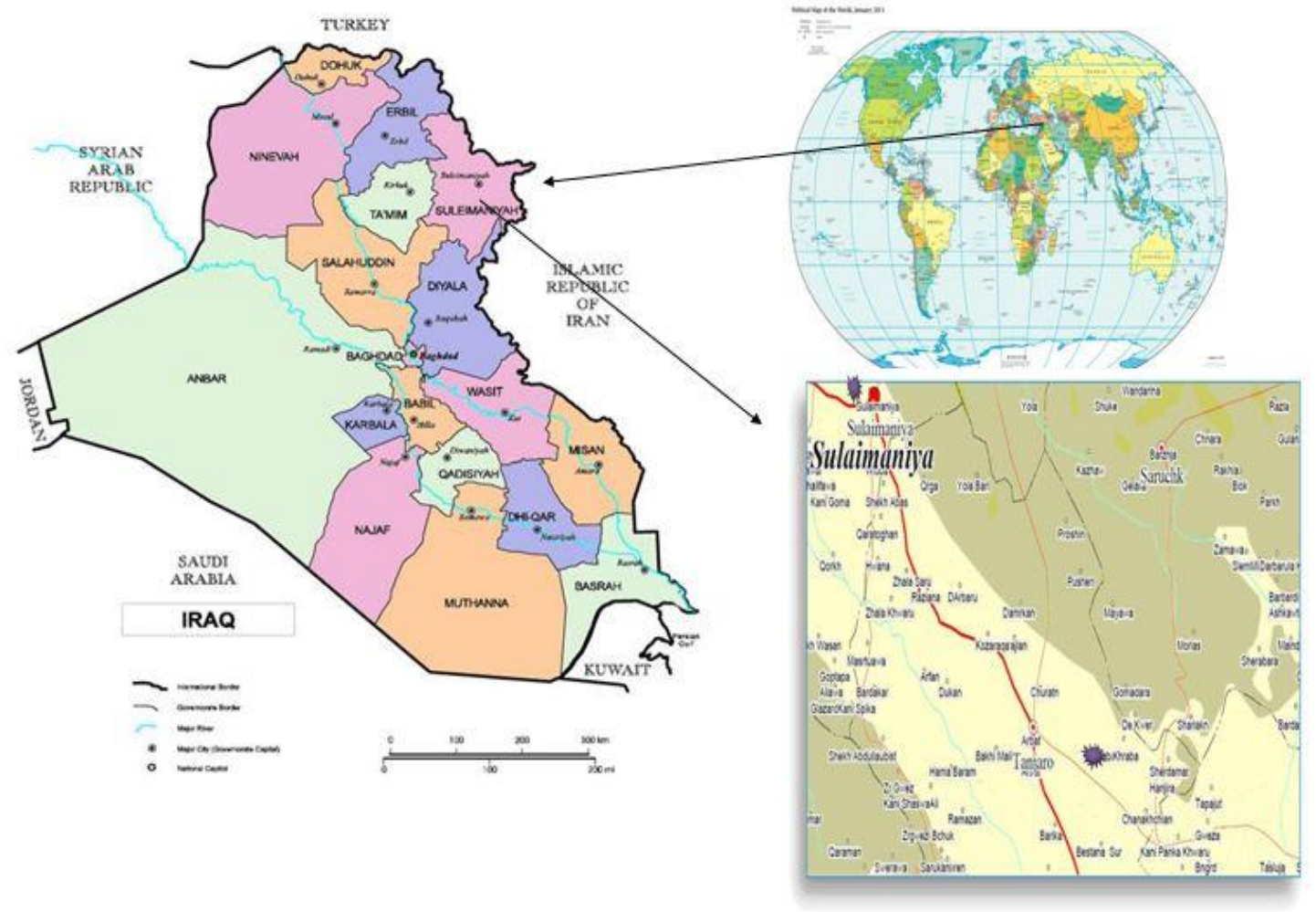

Figure 1. The location of testing site

The experiment was conducted on the $622.5 \mathrm{~m}^{2}$ area $(15 \mathrm{~m} \times 41.5 \mathrm{~m})$, in 16 experimental units with three replicates, the area of each experimental unit was $6 \mathrm{~m}^{2}(2$ $\times 3) \mathrm{m}$, each experimental plot included 3 rows in $3 \mathrm{~m}$ length, and the distance between these three was $0.70 \mathrm{~m}$ while it was $0.30 \mathrm{~m}$ within the rows of the individual plants, to obtain a mean density of 50,000 plants $\mathrm{ha}^{-1}$, and the distance between the experimental units was $0.5 \mathrm{~m}$ while the distance between the blocks was $2 \mathrm{~m}$. Experimental treatments have been organized in a factorial experiment by using the complete randomized block design (CRBD) by having three replicates. Treatments were as follows:

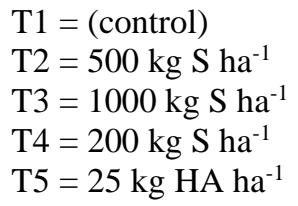

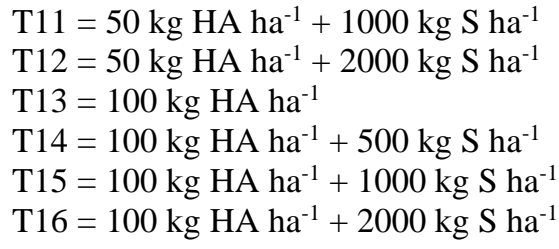


Table 1. Average of the rainfall and air temperature climatic data of the experiment field location (Kanipanka), in 2017

\begin{tabular}{|c|c|c|c|c|c|c|c|c|c|c|c|c|c|c|c|}
\hline \multirow{3}{*}{$\underset{\substack{* \\
\infty}}{\substack{* \\
\infty}}$} & \multicolumn{3}{|c|}{ April } & \multicolumn{3}{|c|}{ May } & \multicolumn{3}{|c|}{ June } & \multicolumn{3}{|c|}{ July } & \multicolumn{3}{|c|}{ August } \\
\hline & \multirow{2}{*}{ 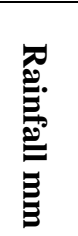 } & \multicolumn{2}{|c|}{$\underset{ }{\text { Temp. }} \stackrel{ }{{ }^{\circ} \mathrm{C}}$} & \multirow{2}{*}{ 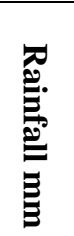 } & \multicolumn{2}{|c|}{$\begin{array}{c}\text { Temp. } \\
{ }^{\circ} \mathbf{C}\end{array}$} & \multirow{2}{*}{ 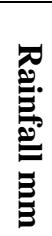 } & \multicolumn{2}{|c|}{$\begin{array}{c}\text { Temp. } \\
{ }^{\circ} \mathrm{C}\end{array}$} & \multirow{2}{*}{ 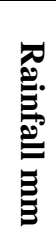 } & \multicolumn{2}{|c|}{$\underset{ }{\text { Temp. }} \underset{{ }^{\circ} \mathbf{C}}{ }$} & \multirow{2}{*}{ 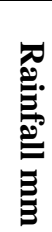 } & \multicolumn{2}{|c|}{$\underset{\substack{\text { Temp. } \\
{ }^{\circ} \mathrm{C}}}{ }$} \\
\hline & & 3. & 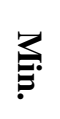 & & 索 & 家 & & 光 & 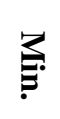 & & 3. & 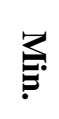 & & 3. & . \\
\hline 1 & 1.2 & 20 & 15 & 1.2 & 28 & 21 & 0 & 30 & 28 & 0 & 40 & 30 & 0 & 44 & 34 \\
\hline 2 & 4.8 & 21 & 16 & 14.5 & 22 & 18 & 0 & 29 & 24 & 0 & 41 & 31 & 0 & 44 & 36 \\
\hline 3 & 15.5 & 16 & 14 & 0 & 27 & 20 & 0 & 33 & 30 & 0 & 42 & 30 & 0 & 43 & 35 \\
\hline 4 & 11 & 18 & 15 & 0 & 27 & 24 & 0 & 35 & 33 & 0 & 44 & 27 & 0 & 44 & 35 \\
\hline 5 & 0 & 23 & 19 & 0 & 25 & 22 & 0 & 36 & 28 & 0 & 44 & 27 & 0 & 44 & 36 \\
\hline 6 & 0 & 24 & 15 & 1.2 & 28 & 17 & 0 & 40 & 30 & 0 & 45 & 31 & 0 & 44 & 35 \\
\hline 7 & 2.5 & 21 & 15 & 0 & 28 & 24 & 0 & 40 & 36 & 0 & 42 & 30 & 0 & 44 & 38 \\
\hline 8 & 0 & 21 & 19 & 0 & 30 & 24 & 0 & 39 & 35 & 0 & 44 & 36 & 0 & 43 & 39 \\
\hline 9 & 0 & 21 & 16 & 0 & 29 & 26 & 0 & 39 & 36 & 0 & 41 & 34 & 0 & 45 & 37 \\
\hline 10 & 0 & 19 & 13 & 0 & 32 & 26 & 0 & 41 & 36 & 0 & 43 & 34 & 0 & 44 & 37 \\
\hline 11 & 3 & 19 & 14 & 0 & 34 & 31 & 0 & 38 & 34 & 0 & 41 & 39 & 0 & 41 & 35 \\
\hline 12 & 0 & 25 & 22 & 0 & 35 & 27 & 0 & 37 & 34 & 0 & 41 & 35 & 0 & 44 & 36 \\
\hline 13 & 7 & 28 & 18 & 0 & 32 & 27 & 0 & 39 & 36 & 0 & 39 & 33 & 0 & 45 & 37 \\
\hline 14 & 8 & 19 & 16 & 0 & 32 & 26 & 0 & 41 & 37 & 0 & 41 & 38 & 0 & 41 & 34 \\
\hline 15 & 0 & 21 & 18 & 0 & 34 & 30 & 0 & 36 & 32 & 0 & 41 & 38 & 0 & 41 & 35 \\
\hline 16 & 0 & 22 & 17 & 0 & 33 & 29 & 0 & 35 & 33 & 0 & 42 & 34 & 0 & 41 & 35 \\
\hline 17 & 0 & 24 & 20 & 0 & 32 & 28 & 0 & 36 & 30 & 0 & 43 & 31 & 0 & 43 & 37 \\
\hline 18 & 5 & 24 & 19 & 0 & 29 & 20 & 0 & 37 & 32 & 0 & 44 & 35 & 0 & 41 & 36 \\
\hline 19 & 0 & 22 & 17 & 1.3 & 35 & 26 & 0 & 38 & 29 & 0 & 44 & 36 & 0 & 41 & 35 \\
\hline 20 & 0 & 24 & 21 & 0 & 32 & 27 & 0 & 37 & 31 & 0 & 43 & 35 & 0 & 41 & 36 \\
\hline 21 & 0 & 24 & 20 & 0 & 27 & 22 & 0 & 34 & 30 & 0 & 44 & 38 & 0 & 42 & 35 \\
\hline 22 & 0 & 28 & 22 & 0 & 29 & 25 & 0 & 34 & 29 & 0 & 44 & 37 & 0 & 43 & 32 \\
\hline 23 & 1 & 26 & 22 & 0 & 32 & 27 & 0 & 38 & 35 & 0 & 45 & 35 & 0 & 42 & 34 \\
\hline 24 & 2.5 & 25 & 20 & 0 & 30 & 26 & 0 & 40 & 32 & 0 & 42 & 34 & 0 & 42 & 34 \\
\hline 25 & 0 & 26 & 20 & 0 & 29 & 27 & 0 & 40 & 31 & 0 & 41 & 37 & 0 & 42 & 34 \\
\hline 26 & 0 & 26 & 23 & 0 & 34 & 27 & 0 & 40 & 32 & 0 & 40 & 33 & 0 & 42 & 34 \\
\hline 27 & 0 & 27 & 25 & 0 & 35 & 28 & 0 & 43 & 36 & 0 & 43 & 36 & 0 & 41 & 34 \\
\hline 28 & 0 & 29 & 25 & 0 & 35 & 27 & 0 & 44 & 35 & 0 & 44 & 38 & 0 & 40 & 32 \\
\hline 29 & 0 & 31 & 23 & 0 & 36 & 32 & 0 & 41 & 36 & 0 & 44 & 39 & 0 & 42 & 35 \\
\hline 30 & 0 & 30 & 27 & 0 & 36 & 27 & 0 & 41 & 37 & 0 & 41 & 33 & 0 & 42 & 34 \\
\hline 31 & & & & 0 & 35 & 29 & & & & 0 & 42 & 31 & 0 & 43 & 32 \\
\hline
\end{tabular}


Table 2. Average of the rainfall and air temperature climatic data of the experiment field location (Qlyasan), in 2017

\begin{tabular}{|c|c|c|c|c|c|c|c|c|c|c|c|c|c|c|c|}
\hline \multirow{3}{*}{ 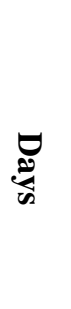 } & \multicolumn{3}{|c|}{ April } & \multicolumn{3}{|c|}{ May } & \multicolumn{3}{|c|}{ June } & \multicolumn{3}{|c|}{ July } & \multicolumn{3}{|c|}{ August } \\
\hline & \multirow{2}{*}{ 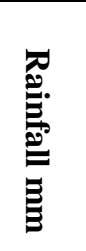 } & \multicolumn{2}{|c|}{$\underset{{ }^{\circ} \mathbf{C}}{\text { Temp. }}$} & \multirow{2}{*}{ 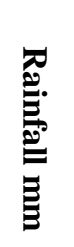 } & \multicolumn{2}{|c|}{$\underset{ }{\text { Temp. }} \underset{{ }^{\circ} \mathbf{C}}{ }$} & \multirow{2}{*}{ 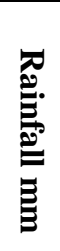 } & \multicolumn{2}{|c|}{$\underset{{ }^{\circ} \mathbf{C}}{\text { Temp. }}$} & \multirow{2}{*}{ 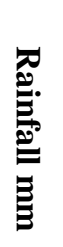 } & \multicolumn{2}{|c|}{$\underset{{ }^{\circ} \mathbf{C}}{\text { Temp. }}$} & \multirow{2}{*}{ 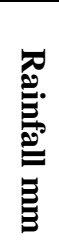 } & \multicolumn{2}{|c|}{$\underset{{ }^{\circ} \mathrm{C}}{\text { Temp. }}$} \\
\hline & & 23: & 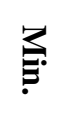 & & 羿 & 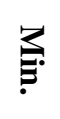 & & 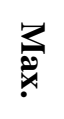 & :3. & & 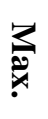 & 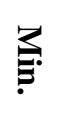 & & جִ & 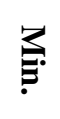 \\
\hline 1 & 2.6 & 22 & 12 & 0.5 & 32 & 22 & 0 & 34 & 24 & 0 & 44 & 36 & 0 & 48 & 40 \\
\hline 2 & 10.2 & 20 & 12 & 15.5 & 29 & 24 & 0 & 36 & 22 & 0 & 43 & 36 & 0 & 47 & 36 \\
\hline 3 & 4.9 & 20 & 16 & 0 & 25 & 23 & 0 & 37 & 21 & 0 & 47 & 34 & 0 & 47 & 38 \\
\hline 4 & 0 & 20 & 18 & 0 & 30 & 19 & 0 & 37 & 31 & 0 & 48 & 35 & 0 & 46 & 38 \\
\hline 5 & 0 & 24 & 17 & 0 & 31 & 23 & 0 & 41 & 28 & 0 & 47 & 34 & 0 & 48 & 32 \\
\hline 6 & 0 & 26 & 21 & 0 & 31 & 20 & 0 & 42 & 25 & 0 & 46 & 35 & 0 & 44 & 34 \\
\hline 7 & 0 & 26 & 21 & 0 & 26 & 19 & 0 & 44 & 29 & 0 & 46 & 35 & 0 & 45 & 36 \\
\hline 8 & 1.7 & 24 & 20 & 0 & 32 & 22 & 0 & 38 & 33 & 0 & 47 & 36 & 0 & 47 & 39 \\
\hline 9 & 0 & 23 & 20 & 1.3 & 34 & 27 & 0 & 38 & 26 & 0 & 39 & 34 & 0 & 46 & 35 \\
\hline 10 & 0 & 22 & 21 & 0 & 36 & 24 & 0 & 37 & 33 & 0 & 43 & 35 & 0 & 49 & 36 \\
\hline 11 & 4 & 20 & 16 & 0 & 39 & 24 & 0 & 43 & 31 & 0 & 45 & 28 & 0 & 46 & 35 \\
\hline 12 & 5.5 & 29 & 23 & 0 & 38 & 24 & 0 & 42 & 27 & 0 & 45 & 29 & 0 & 48 & 36 \\
\hline 13 & 0 & 31 & 29 & 0 & 32 & 22 & 0 & 42 & 36 & 0 & 37 & 33 & 0 & 48 & 37 \\
\hline 14 & 6.2 & 22 & 20 & 0 & 36 & 22 & 0 & 44 & 35 & 0 & 43 & 34 & 0 & 46 & 32 \\
\hline 15 & 0 & 24 & 17 & 0 & 37 & 24 & 0 & 37 & 35 & 0 & 41 & 28 & 0 & 43 & 31 \\
\hline 16 & 0 & 23 & 18 & 0 & 36 & 22 & 0 & 38 & 32 & 0 & 44 & 34 & 0 & 44 & 31 \\
\hline 17 & 0 & 27 & 20 & 0 & 35 & 22 & 0 & 41 & 26 & 0 & 46 & 31 & 0 & 44 & 36 \\
\hline 18 & 5.4 & 29 & 24 & 0 & 34 & 20 & 0 & 42 & 27 & 0 & 46 & 33 & 0 & 37 & 34 \\
\hline 19 & 0 & 24 & 17 & 2.7 & 39 & 33 & 0 & 40 & 29 & 0 & 46 & 33 & 0 & 44 & 34 \\
\hline 20 & 0 & 24 & 17 & 0 & 33 & 28 & 0 & 40 & 27 & 0 & 45 & 37 & 0 & 43 & 34 \\
\hline 21 & 0 & 28 & 16 & 0 & 28 & 22 & 0 & 37 & 30 & 0 & 46 & 42 & 0 & 46 & 29 \\
\hline 22 & 0 & 26 & 20 & 0 & 30 & 22 & 0 & 36 & 24 & 0 & 48 & 37 & 0 & 45 & 32 \\
\hline 23 & 1.5 & 28 & 22 & 0 & 34 & 25 & 0 & 38 & 23 & 0 & 48 & 35 & 0 & 41 & 30 \\
\hline 24 & 0.2 & 26 & 24 & 0 & 31 & 24 & 0 & 41 & 28 & 0 & 44 & 34 & 0 & 41 & 30 \\
\hline 25 & 0 & 29 & 20 & 0 & 33 & 21 & 0 & 42 & 26 & 0 & 43 & 32 & 0 & 44 & 31 \\
\hline 26 & 0 & 28 & 20 & 0 & 34 & 20 & 0 & 44 & 32 & 0 & 43 & 33 & 0 & 44 & 30 \\
\hline 27 & 0 & 29 & 23 & 0 & 35 & 29 & 0 & 47 & 40 & 0 & 45 & 28 & 0 & 44 & 32 \\
\hline 28 & 0 & 30 & 23 & 0 & 37 & 23 & 0 & 48 & 35 & 0 & 47 & 33 & 0 & 44 & 26 \\
\hline 29 & 0 & 32 & 26 & 0 & 40 & 24 & 0 & 45 & 31 & 0 & 44 & 32 & 0 & 45 & 30 \\
\hline 30 & 0 & 34 & 27 & 0 & 40 & 27 & 0 & 45 & 30 & 0 & 44 & 33 & 0 & 44 & 30 \\
\hline 31 & & & & 0 & 36 & 35 & & & & 0 & 44 & 31 & 0 & 46 & 32 \\
\hline
\end{tabular}


All required management practices were done at proper times, and the standard practices were used for weed control. Soil samples were taken before planting from a depth of $0-40 \mathrm{~cm}$ of the soil used in the field experiments. The soil samples were airdried, filtered by a $2 \mathrm{~mm}$ sieve, and kept in plastic bottles until analyzed. (Table 3) illustrates the main physical and chemical properties of the soils.

Table 3. Some physical and chemical properties of soil used in field experiments

\begin{tabular}{|c|c|c|c|}
\hline & & \multicolumn{2}{|c|}{ Location } \\
\hline \multirow{4}{*}{ Particle size distribution (PSD) $\mathrm{g} \mathrm{kg}^{-1}$} & & Qlyasan & Kanipanka \\
\hline & Sand & 59.68 & 37.40 \\
\hline & Silt & 619.17 & 500.30 \\
\hline & Clay & 321.15 & 462.30 \\
\hline \multicolumn{2}{|l|}{ Textural class } & Silty clay loam & Silty clay \\
\hline \multicolumn{2}{|l|}{ Bulk density $\mathrm{Mg} \mathrm{m}^{-3}$} & 1.40 & 1.50 \\
\hline \multicolumn{2}{|l|}{$\mathrm{pH}$} & 7.42 & 7.46 \\
\hline \multicolumn{2}{|l|}{ 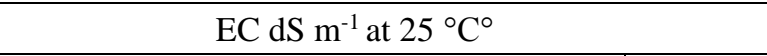 } & 0.38 & 0.27 \\
\hline \multirow{6}{*}{$\begin{array}{l}\text { Soluble ions } \\
\mathrm{mmol} \mathrm{L}^{-1}\end{array}$} & $\mathrm{Ca}^{2+}$ & 2.0 & 4.20 \\
\hline & $\mathrm{Mg}^{2+}$ & 0.81 & 0.90 \\
\hline & $\mathrm{Na}^{+}$ & 0.46 & 0.80 \\
\hline & $\mathrm{K}^{+}$ & 0.156 & 2.70 \\
\hline & $\mathrm{HCO}_{3}^{-}$ & 2.51 & 4.20 \\
\hline & $\mathrm{SO}_{4}{ }^{2-}$ & 0.789 & 0.892 \\
\hline \multicolumn{2}{|c|}{ Cation exchange capacity (CEC) cmolckg $^{-1}$} & 49.82 & 46.50 \\
\hline \multicolumn{2}{|c|}{ Organic matter $(\mathrm{OM}) \mathrm{g} \mathrm{kg}^{-1}$} & 19.59 & 22.50 \\
\hline $\mathrm{CaCO}_{3}$ equivalent $\mathrm{g} \mathrm{kg}^{-1}$ & Total & 215.68 & 215.50 \\
\hline
\end{tabular}

Physiological parameters were measured as follows: Three plants of each plot were tagged, and all the reproductive growth and vegetative growth parameters were recorded, leaf area per plant, all available leaves of five plants per net plot were collected at 50\% milking stage, and leaf length and width were measured. The leaf area was determined by multiplying leaf length and maximum leaf width adjusted by a correction factor of 0.75 (i.e., $0.75 \mathrm{X}$ leaf length $\mathrm{X}$ maximum leaf width) as suggested by Francis et al. (1969).

$$
\text { Leaf area }(\mathrm{LA})=\text { Length }(\mathrm{cm}) \times \text { Maximum width of leaf }(\mathrm{cm}) \times 0.75
$$

The diameter of the ear of maize was measured at harvest and expressed in centimeter. The randomly selected ears were cleaned, and a number of rows in each ear were counted manually. Then, the average number of rows of selected ears was taken as the number of rows per Ear. The number of Kernel was obtained by manual counting after separation of Kernels from the ear and the row.

At maturity, the crop was harvested on 27/7/2017 for Kanipanka location and 29/7/2017 for Qlyasan location, after reaching the mature physiological stage (when maturity symptoms occur on plants). Six plants were harvested from each treatment which signed previously, the ears were separated from plants, for removing the dust 
from plants, plants washed by tap water, then rinsed three times by distilled water, air dried in dry cabinets chamber at $70{ }^{\circ} \mathrm{C}$ till the weight fixed at constant weight, and the plants total dry matter weight were recorded. Then, the plants were chopped into small pieces to enable complete drying and then oven-dried at $70{ }^{\circ} \mathrm{C}$ till a constant weight was obtained. The oven-dry weight of dry matter was recorded and expressed in grams per plant. Maize ears were dried, then shelled and the maize grain dried to $15 \%$ moisture content. The dry maize grains were weighed from each harvested area. The weight of grain for each experimental unit $\left(6 \mathrm{~m}^{2}\right)$ was determined, and the yield was expressed in $\left(\mathrm{Mg} \mathrm{ha}^{-1}\right)$. Other yield parameters were also collected.

A small sample of the seeds selected randomly from the grain yield of each experimental unit, and 100 seeds were counted and weighted, to obtain the net weight of 100 seeds $(\mathrm{g})$. Kernel yield (ton $\mathrm{ha}^{-1}$ ) was obtained in ton per hector according to Wasonga et al. (2008) using the following equation:

$$
\text { Kernel yield }\left(\text { ton } \mathrm{ha}^{-1}\right)=\text { Plant density ha }{ }^{-1} \times \text { Grain yield kg plant }^{-1}
$$

Higher harvest index indicates a superior conversion of dry matter to grain yield. Many workers currently (Sharma et al., 1987) calculate harvest index for grain crops as a percentage, thus:

$$
\text { Harvest index }(\%)=(\text { Kernel yield } / \text { Biological yield }) \times 100
$$

The relative yield was calculated by the following equation according to Tisdale et al. (1995):

$$
\text { Relative yield }=(\text { yield of the control/ yield of fertilized treatment }) \times 100 \quad(\text { Eq.4 })
$$

Data were subjected to analysis of variance (ANOVA) performed by XLSTAT (2016) Package and the differences were compared by Duncan Multiple Range Test (DMRT) at the 5\% significance level.

\section{Results}

The attained results will be presented as follows:

\section{Vegetative growth criteria}

\section{Leaf area $\left(\mathrm{cm}^{2}\right)$}

The results in (Figs. 2 and 3) refer to the significant effect of humic acid and sulfur rate fertilizer on the leaf area $\left(\mathrm{cm}^{2}\right)$ of a maize plant. The results showed that the increasing humic acid and sulfur fertilizer application increased the leaf area significantly. The maximum leaf area of maize $\left(78.50\right.$ and $\left.77.50 \mathrm{~cm}^{2}\right)$ was produced by $\mathrm{T}_{16}$ from both of locations Qlyasan and Kanipanka, while the minimum leaf area of maize $\left(66.75 \mathrm{~cm}^{2}\right)$ was produced by $\mathrm{T}_{3}$ and $\mathrm{T}_{1}$ from Qlyasan and Kanipanka locations respectively. Similar results were obtained by Erdal et al. (2000) and Abdullah et al. (2016) for humic acid. While the results were obtained by Nader and Nadia (2011) and Habtamu (2015) for sulfur rates, they found that the application of humic acid and sulfur rate fertilizer were affected significantly in the leaf area $\left(\mathrm{cm}^{2}\right)$ of maize. 


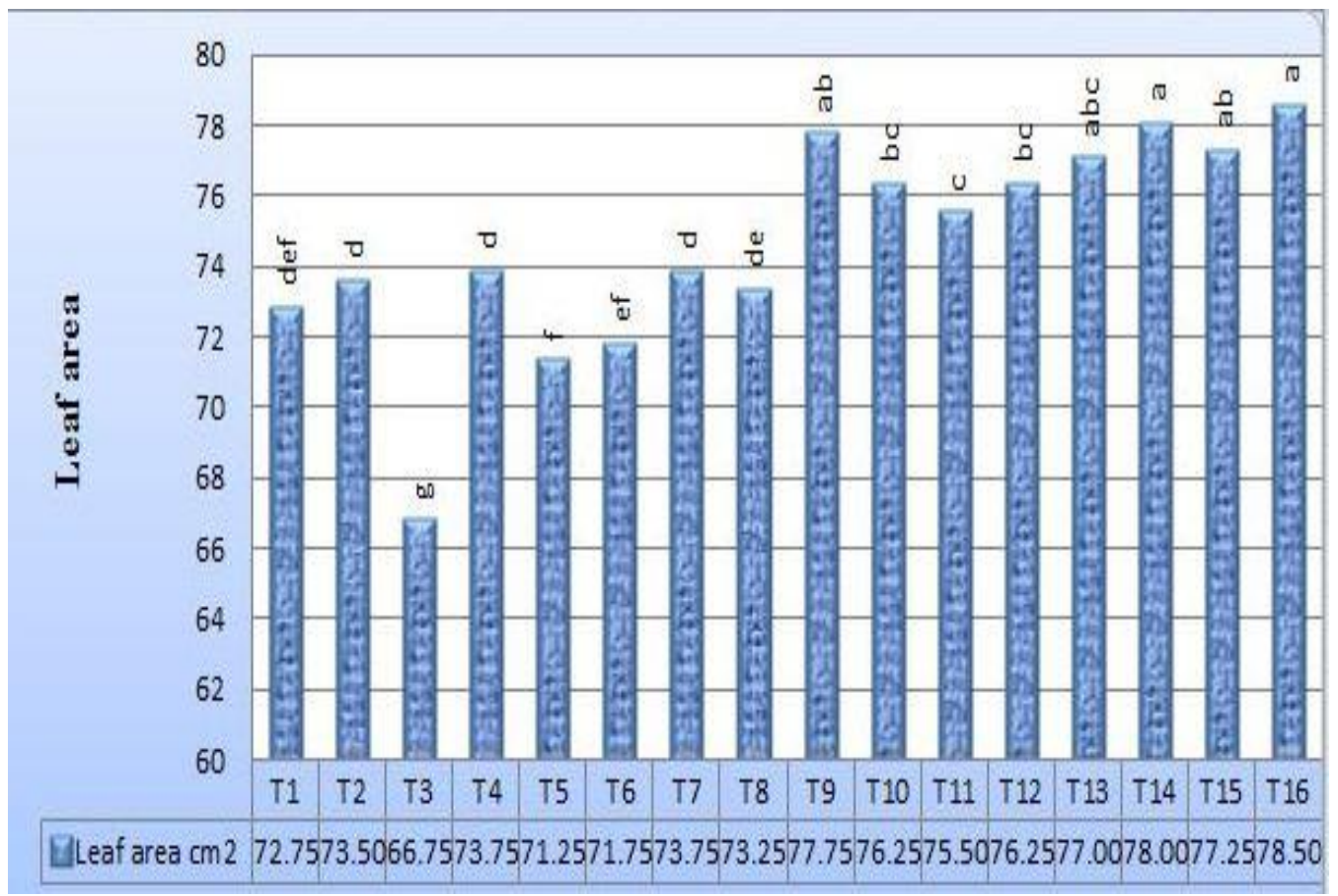

Figure 2. Influence of humic acid and sulfur on the leaf area of maize from Qlyasan location

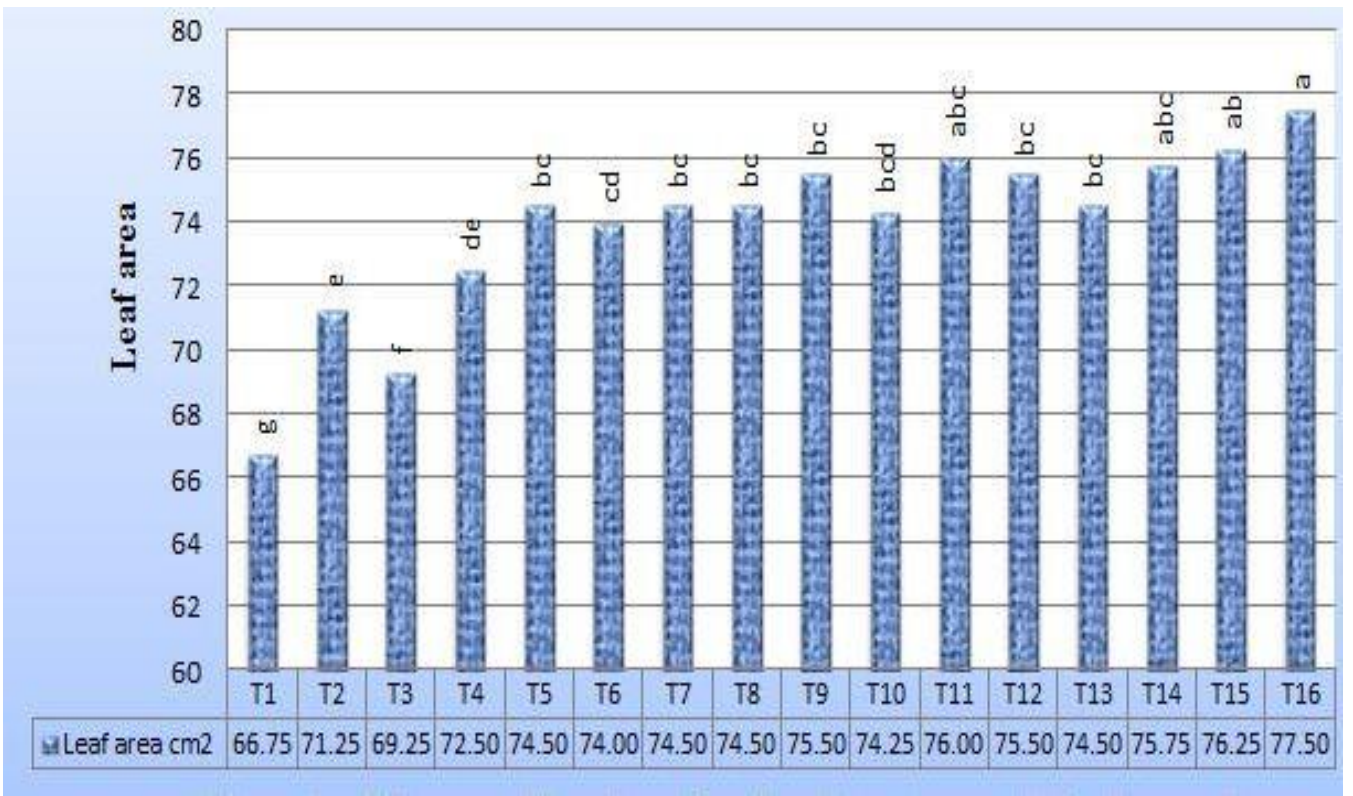

Figure 3. Influence of humic acid and sulfur on the leaf area of maize from Kanipanka location

\section{Reproductive growth criteria}

\section{Ear diameter $(\mathrm{cm})$}

The data presented in (Table 4) shows that the application of humic acid and sulfur rates were affected significantly at $(\mathrm{P}<0.05$ level $)$ on the ear diameter $(\mathrm{cm})$ from the Qlyasan location, the highest value $(4.67 \mathrm{~cm})$ was recorded from $\left(\mathrm{T}_{16}\right)$, while the lowest 
value $(4.26 \mathrm{~cm})$ was obtained from $\left(\mathrm{T}_{11}\right)$. The positive effect of humic acid confirmed with the finding of Ebtisam et al. (2012) and Daur and Ahmed (2013) and similar results obtained by Makary (2002) and Nader and Nadia (2011) for the sulfur rate fertilizer application they referred that the application of humic acid and sulfur are essential to increase the ear characters of the corn plant. While the data present in (Table 5) revealed that, the application of different rates of humic acid and sulfur have not significant effects on the ear diameter $(\mathrm{cm})$ from Kanipanka location.

\section{Number of rows per ear}

Results from a meaningful comparison of data (Tables 4 and 5) of study treatments indicate that humic acid and sulfur rate application to the soil were affected significantly on the number of rows per ear of maize. The highest value of the number of rows per ear (16.67) was recorded from $\left(\mathrm{T}_{12}\right)$, while the lowest value (14.00) was obtained from $\left(\mathrm{T}_{2}\right)$ for Qlyasan location, but for Kanipanka location the highest value of the number of rows per ear (17.67) was recorded from $\left(\mathrm{T}_{16}\right)$, while the lowest value (15.33) was obtained from $\left(\mathrm{T}_{1}\right)$. Similar results were obtained by Attia et al. (2013) and Muhammad et al. (2015) for humic acid, and were obtained by Khan et al. (2006) and Habtamu (2015) for sulfur rates application, they found that the application of humic acid and sulfur rate affected significantly on the number of rows per ear of maize.

Table 4. Influence of humic acid and sulfur rates on reproductive growth criteria of maize from Qlyasan location

\begin{tabular}{|c|c|c|c|c|c|c|c|c|}
\hline Treat. & $\begin{array}{c}\text { Ear } \\
\text { diameter } \\
(\mathbf{c m})\end{array}$ & $\begin{array}{c}\text { No. of } \\
\text { (row/ear) }\end{array}$ & $\begin{array}{c}\text { No. of } \\
\text { (kernel/row) }\end{array}$ & $\begin{array}{c}\text { No. of } \\
(\text { kernel/ear) }\end{array}$ & $\begin{array}{l}\text { Weight of } \\
100 \text { kernel } \\
\text { (g) }\end{array}$ & $\begin{array}{c}\text { Kernel } \\
\text { yield } \\
\left(\text { ton }^{-1} \mathbf{a}^{-1}\right)\end{array}$ & $\begin{array}{c}\text { Biological } \\
\text { yield } \\
\left(\text { ton } \text { ha }^{-1}\right)\end{array}$ & $\underset{\%}{\mathrm{HI}}$ \\
\hline $\mathrm{T}_{1}$ & $4.29 \mathrm{bc}$ & $14.67^{b c}$ & $40.81^{b c}$ & $598.67^{\mathrm{de}}$ & $22.65^{\mathrm{de}}$ & $6.44 \mathrm{hi}$ & $22.79^{\mathrm{f}}$ & $28.27^{\text {fgh }}$ \\
\hline $\mathrm{T}_{2}$ & $4.38^{c}$ & $14.00^{c}$ & $42.31^{b c}$ & 598.87 de & $22.26^{\text {ef }}$ & $6.26^{\mathrm{hi}}$ & $22.68^{\mathrm{f}}$ & $27.59^{\text {gh }}$ \\
\hline $\mathrm{T}_{3}$ & $4.38^{c}$ & $14.33^{c}$ & $41.79^{b c}$ & $598.97 \mathrm{de}$ & $23.28^{\mathrm{de}}$ & $8.22^{\mathrm{d}}$ & $23.05^{\mathrm{ef}}$ & $35.68^{\mathrm{ab}}$ \\
\hline $\mathrm{T}_{4}$ & $4.29^{c}$ & $14.00^{c}$ & $42.76^{b c}$ & $598.67^{\mathrm{de}}$ & $21.50^{f}$ & $6.83^{\mathrm{fgh}}$ & $23.21^{\mathrm{def}}$ & $29.47^{\text {defg }}$ \\
\hline $\mathrm{T}_{5}$ & $4.45^{b c}$ & $14.67^{b c}$ & $41.90^{b c}$ & $614.67^{\mathrm{de}}$ & $22.89^{\mathrm{de}}$ & $5.91^{\mathrm{i}}$ & $21.34^{\text {cdef }}$ & $27.69^{\mathrm{h}}$ \\
\hline $\mathrm{T}_{6}$ & $4.38^{c}$ & $14.33^{c}$ & $43.07^{b c}$ & $616.67^{\mathrm{de}}$ & $23.14^{\text {de }}$ & $6.49 \mathrm{ghi}$ & $23.52^{\text {cdef }}$ & $27.62^{\mathrm{gh}}$ \\
\hline $\mathrm{T}_{7}$ & $4.29^{c}$ & $14.00^{c}$ & $42.33^{b c}$ & $599.67^{\mathrm{e}}$ & $22.79 \mathrm{de}$ & $6.77 \mathrm{gh}$ & $23.37^{\text {cdef }}$ & $28.99^{\text {efgh }}$ \\
\hline $\mathrm{T}_{8}$ & $4.59^{\mathrm{ab}}$ & $15.67^{\mathrm{ab}}$ & $42.00^{b c}$ & $658.67 \mathrm{bcd}$ & $23.18^{\mathrm{de}}$ & $7.47^{\mathrm{ef}}$ & $23.81^{\text {cde }}$ & $31.36^{\text {cdef }}$ \\
\hline $\mathrm{T}_{9}$ & $4.37^{\mathrm{c}}$ & $14.33^{c}$ & $44.33^{a b c}$ & $635.67^{\mathrm{cde}}$ & $23.54^{\mathrm{cd}}$ & $8.00 \mathrm{de}$ & $24.06^{\mathrm{cd}}$ & $33.24^{\mathrm{bc}}$ \\
\hline $\mathrm{T}_{10}$ & $4.26^{c}$ & $14.67^{c}$ & $42.33^{\mathrm{a}}$ & $635.65^{\text {bcde }}$ & $23.70^{\mathrm{cd}}$ & $8.93^{\mathrm{a}}$ & $24.06^{\mathrm{cd}}$ & $37.14^{\mathrm{a}}$ \\
\hline $\mathrm{T}_{11}$ & $4.45^{\mathrm{bc}}$ & $14.67^{b c}$ & $43.67^{\mathrm{c}}$ & $640.64^{\mathrm{de}}$ & $24.61^{b c}$ & $9.12^{b}$ & $24.13^{b c}$ & $37.79^{\mathrm{a}}$ \\
\hline $\mathrm{T}_{12}$ & $4.65^{\mathrm{a}}$ & $16.67^{\mathrm{a}}$ & $45.33^{\mathrm{ab}}$ & $754.67^{\mathrm{a}}$ & $25.23^{b}$ & $7.82 \mathrm{de}$ & $24.14^{b c}$ & $32.38^{\text {bcde }}$ \\
\hline $\mathrm{T}_{13}$ & $4.61^{\mathrm{ab}}$ & $16.00^{\mathrm{a}}$ & $42.67^{b c}$ & $682.67^{b c}$ & $26.38^{a}$ & $8.20^{\mathrm{d}}$ & $24.92^{\mathrm{b}}$ & $32.94^{\mathrm{bcd}}$ \\
\hline $\mathrm{T}_{14}$ & $4.61^{\mathrm{ab}}$ & $16.33^{\mathrm{a}}$ & $42.84^{b c}$ & $698.67^{a b}$ & $26.55^{\mathrm{a}}$ & $7.12^{\mathrm{fg}}$ & $26.03^{a}$ & $27.35^{\mathrm{gh}}$ \\
\hline $\mathrm{T}_{15}$ & $4.65^{\mathrm{a}}$ & $16.33^{\mathrm{a}}$ & $43.81^{b c}$ & $695.00^{\mathrm{bc}}$ & $26.64^{\mathrm{a}}$ & $9.93^{b c}$ & $26.00^{\mathrm{a}}$ & $38.20^{\mathrm{a}}$ \\
\hline $\mathrm{T}_{16}$ & $4.67^{\mathrm{a}}$ & $16.33^{\mathrm{a}}$ & $42.90^{\mathrm{bc}}$ & $699.67^{\mathrm{ab}}$ & $27.02^{\mathrm{a}}$ & $8.44^{\mathrm{cd}}$ & $26.15^{\mathrm{a}}$ & $32.29^{\text {bcde }}$ \\
\hline
\end{tabular}

Treat. $=$ Treatments, No. $=$ Number, $\mathrm{HI}=$ Harvest index

\section{Number of kernels per row and ear}

The application of humic acid and sulfur rate fertilizer significantly increased the kernel per row of maize. The highest mean value of kernel per ear (754.67) was 
recorded from (T12), while the lowest mean value of kernel per ear (598.67) was obtained from (T1) for Qlyasan location (Table 4), but for Kanipanka location the highest value of kernel per ear (768.00) was recorded from (T16), while the lowest value of kernel per ear (648.33) was obtained from (T2) (Table 5). Similar results were obtained by Celiket al. (2010) for humic acid, and the results are in agreement with those obtained by Choudhary et al. (2013) for sulfur rate application, they found that the application of humic acid and sulfur rates affected significantly of the kernel per ear of maize. From the results in (Tables 4 and 5) it has been observed that the application of humic acid and sulfur rates have not a significant effect on a number of kernels per row in Qlyasan location but have a significant effect in Kanipanka location.

\section{The weight of 100 kernels $(g)$}

According to the analysis of variance, the mean comparison showed that the application rates of humic acid and sulfur revealed that the weight of 100 kernels $(\mathrm{g})$ of maize was affected significantly at $(\mathrm{P}<0.05)$. The results show that significantly increased the weight of 100 kernels ( $\mathrm{g}$ ) of maize from $22.26 \mathrm{~g}$ was recorded from (T2) to $27.02 \mathrm{~g}$ was recorded from (T16) for Qlyasan location (Table 4) and from $27.33 \mathrm{~g}$ was recorded from (T1) to $33.92 \mathrm{~g}$ was recorded from (T16) for Kanipanka location (Table 5). These findings are in coincidence with those recorded by Navigehet al. (2012) and Balbaaet al. (2013) about humic acid, and the results are in agreement with those obtained by Srinivasraoet al. (2010) about the sulfur rate application, they found that the application of humic acid and sulfur rates affected the weight of 100 kernels $(\mathrm{g})$ of maize significantly.

\section{Kernel yield (ton $\mathrm{ha}^{-1}$ )}

The data relating to kernel yield (ton $\mathrm{ha}^{-1}$ ) are presented in (Tables 4 and 5), revealed that kernel yield was affected significantly at $(\mathrm{P}<0.05$ level $)$ by the application of humic acid and sulfur rate to the soil. The maximum of kernel yield (9.93 and 9.20 ton $\mathrm{ha}^{-1}$ ) was produced by $\mathrm{T} 15$ and $\mathrm{T} 13$, while the minimum kernel yield (6.26 and 7.22 ton $\mathrm{ha}^{-1}$ ) was produced by T2 and T1 from Qlyasan and Kanipanka locations respectively. Similar results were obtained by Turanet al. (2011), and Awwadet al. (2015) about humic acid and the results are in a harmonic with the finding by Khan et al. (2006) about sulfur rates application, they found that the application of humic acid and sulfur rate affected significantly of the kernel yield $\left(\right.$ ton ha $\left.{ }^{-1}\right)$ of maize.

\section{Biological yield (ton $\left.\mathrm{ha}^{-1}\right)$}

The result regarding biological yield (ton $\mathrm{ha}^{-1}$ ) of maize plant showed that the application of humic acid and sulfur rates to the soil was affected significantly at $(\mathrm{P}<0.05)$ on biological yield from both locations Qlyasan and Kanipanka. The maximum biological yield (26.15 and 26.54 ton ha $\mathrm{ha}^{-1}$ ) was obtained from T16 and T15, while the minimum biological yield (22.68 and 22.6 ton ha ${ }^{-1}$ ) was obtained from T2 and T1 for both locations Qlyasan and Kanipanka respectively (Tables 4 and 5). These results are in a harmonic with those recorded by Gomaa et al. (2014) and Daur and Ahmed (2013) for humic acid, and the results are in agreement with the finding by Khan et al. (2006); Choudhary et al. (2013) and Habtamu (2015) for sulfur rate application, they found that the application of humic acid and sulfur rates affected significantly of the biological yield (ton ha ${ }^{-1}$ ) of maize. 
Table 5. Influence of humic acid and sulfur rates on reproductive growth criteria of maize from Kanipanka location

\begin{tabular}{|c|c|c|c|c|c|c|c|c|}
\hline Treat. & $\begin{array}{c}\text { Ear } \\
\text { diameter } \\
(\mathrm{cm})\end{array}$ & $\begin{array}{c}\text { No. of } \\
\text { (row/ear) }\end{array}$ & $\begin{array}{c}\text { No. of } \\
\text { (kernel/row) }\end{array}$ & $\begin{array}{c}\text { No. of } \\
\text { (kernel/ear) }\end{array}$ & $\begin{array}{l}\text { Weight of } \\
100 \text { kernel } \\
\text { (g) }\end{array}$ & \begin{tabular}{|c|} 
Kernel \\
yield \\
$\left(\right.$ ton ha $^{-1}$ )
\end{tabular} & $\begin{array}{c}\text { Biological } \\
\text { yield } \\
\left(\text { ton ha }^{-1}\right)\end{array}$ & $\begin{array}{l}\mathrm{HI} \\
\%\end{array}$ \\
\hline $\mathrm{T}_{1}$ & $4.60^{\mathrm{b}}$ & $15.33^{\mathrm{de}}$ & $42.40^{\text {bcdef }}$ & $678.33^{\text {cd }}$ & $27.33^{\text {ef }}$ & $7.22^{\mathrm{d}}$ & $22.6^{\mathrm{g}}$ & $31.83^{\text {cdef }}$ \\
\hline $\mathrm{T}_{2}$ & $4.58^{\mathrm{b}}$ & $15.33^{\mathrm{de}}$ & $40.52^{\mathrm{f}}$ & $648.33^{\mathrm{d}}$ & $27.36^{\mathrm{fg}}$ & $7.55^{\mathrm{cd}}$ & $25.98 \mathrm{abc}$ & $29.06^{\mathrm{h}}$ \\
\hline $\mathrm{T}_{3}$ & $4.58^{\mathrm{b}}$ & $15.47^{\mathrm{de}}$ & $41.77^{\mathrm{cdef}}$ & $654.33^{\mathrm{d}}$ & $28.06^{\mathrm{ef}}$ & $7.60^{\mathrm{cd}}$ & $23.27^{\mathrm{fg}}$ & $32.69^{\mathrm{bcd}}$ \\
\hline $\mathrm{T}_{4}$ & $4.52^{\mathrm{b}}$ & $15.33^{\mathrm{de}}$ & $44.84^{\mathrm{ab}}$ & $686.33^{\mathrm{cd}}$ & $26.45^{\mathrm{g}}$ & $8.33^{\mathrm{b}}$ & $25.44^{\mathrm{cd}}$ & $32.75^{\mathrm{bcd}}$ \\
\hline $\mathrm{T}_{5}$ & $4.61^{\mathrm{b}}$ & $16.00^{\mathrm{e}}$ & $43.67^{\text {abcde }}$ & $698.33^{\mathrm{bcd}}$ & $28.87^{\mathrm{e}}$ & $7.27^{\mathrm{d}}$ & $23.67^{f}$ & 30.72 efgh \\
\hline $\mathrm{T}_{6}$ & $4.61^{\mathrm{b}}$ & $16.00^{\mathrm{e}}$ & $44.00^{\mathrm{abcde}}$ & $704.00^{\mathrm{bcd}}$ & $28.86^{\mathrm{e}}$ & $7.38^{\mathrm{d}}$ & $24.39^{\mathrm{e}}$ & $30.26^{\mathrm{fgh}}$ \\
\hline $\mathrm{T}_{7}$ & $5.64^{\mathrm{a}}$ & $16.33^{\text {cde }}$ & $41.67^{\text {def }}$ & $680.33^{\mathrm{cd}}$ & $28.04^{\mathrm{ef}}$ & $7.40^{\mathrm{d}}$ & $24.58^{\mathrm{e}}$ & $30.10^{\text {fgh }}$ \\
\hline $\mathrm{T}_{8}$ & $4.66^{\mathrm{b}}$ & $16.33^{\text {cde }}$ & $44.67^{\mathrm{ab}}$ & $729.33^{\mathrm{abc}}$ & $31.79^{\mathrm{cd}}$ & $7.22^{\mathrm{d}}$ & $22.95 \mathrm{de}$ & $31.46^{\mathrm{h}}$ \\
\hline $\mathrm{T}_{9}$ & $4.64^{\mathrm{b}}$ & $16.33^{\text {cde }}$ & $44.67^{\mathrm{abc}}$ & $730.00^{\mathrm{abc}}$ & $28.43^{\mathrm{ef}}$ & $9.04^{\mathrm{a}}$ & $25.48^{\mathrm{cd}}$ & $35.47^{\mathrm{a}}$ \\
\hline $\mathrm{T}_{10}$ & $4.61^{\mathrm{b}}$ & $16.00^{\mathrm{de}}$ & $45.67^{\mathrm{a}}$ & $730.67^{\mathrm{abc}}$ & $28.99^{\mathrm{e}}$ & $7.51^{\mathrm{cd}}$ & $25.47^{\mathrm{cd}}$ & $29.50^{\mathrm{gh}}$ \\
\hline $\mathrm{T}_{11}$ & $4.66^{\mathrm{b}}$ & $16.33^{\text {cde }}$ & $41.33^{\mathrm{ef}}$ & $675.00^{\mathrm{cd}}$ & $32.54^{\mathrm{bc}}$ & $7.53^{\text {cd }}$ & $23.39^{\mathrm{fg}}$ & $32.30^{\text {cde }}$ \\
\hline $\mathrm{T}_{12}$ & $4.75^{\mathrm{b}}$ & $17.63^{\mathrm{b}}$ & $42.68^{\mathrm{ab}}$ & $754.16^{\mathrm{a}}$ & $31.11^{\mathrm{d}}$ & $7.91^{\mathrm{c}}$ & $25.38^{\mathrm{cd}}$ & $31.15^{\operatorname{defg}}$ \\
\hline $\mathrm{T}_{13}$ & $4.84^{\mathrm{b}}$ & $19.00^{\mathrm{a}}$ & $39.70^{\mathrm{f}}$ & $754.33^{\mathrm{ab}}$ & $33.19^{\mathrm{ab}}$ & $9.20^{\mathrm{a}}$ & $25.62 \mathrm{bcd}$ & $35.93^{a}$ \\
\hline $\mathrm{T}_{14}$ & $4.68^{\mathrm{b}}$ & $17.00^{\mathrm{bcd}}$ & $44.54^{\mathrm{abcd}}$ & $757.00^{\mathrm{ab}}$ & $33.10^{\mathrm{ab}}$ & $8.89^{\mathrm{a}}$ & $25.78^{\mathrm{bc}}$ & $34.51^{\mathrm{ab}}$ \\
\hline $\mathrm{T}_{15}$ & $4.68^{\mathrm{b}}$ & $16.67^{\text {bde }}$ & $45.33^{\mathrm{ab}}$ & $755.67^{\mathrm{ab}}$ & $32.45^{\mathrm{bc}}$ & $8.84^{\mathrm{a}}$ & $26.54^{\mathrm{a}}$ & $33.29 \mathrm{bc}$ \\
\hline $\mathrm{T}_{16}$ & $4.77^{\mathrm{b}}$ & $17.67^{\mathrm{bc}}$ & $43.49^{\text {abcde }}$ & $768.00^{\mathrm{a}}$ & $33.92^{\mathrm{a}}$ & $9.12^{\mathrm{a}}$ & $26.36^{\mathrm{ab}}$ & $34.61^{\mathrm{ab}}$ \\
\hline
\end{tabular}

Treat. $=$ Treatments, No. $=$ Number, $\mathrm{HI}=$ Harvest index

\section{Harvest index \%}

The statistical analysis of the variance in (Tables 4 and 5) showed that applying humic acid and sulfur rate for the soil was affected significantly at $(\mathrm{P}<0.05$ level $)$ on harvest index. The highest value of harvest index percentage $(38.20 \%$ and $35.93 \%)$ was recorded from $\mathrm{T} 15$ and $\mathrm{T} 13$, while the lowest value of harvest index percentage (27.59\% and 29.06\%) was observed in T2 from Qlyasan and Kanipanka locations respectively. These results for humic acid were in agreement with the results of Celiketal (2010) and Awwadet al. (2015) who found that the harvest index increased owing to the increase of humic acid rates. About the effect of sulfur rates, the results in a harmonic with the results of Szulcet al. (2012), reported that the different levels of a sulfur application significantly affected the grain yield and harvest index of maize plans.

\section{Relative yield percentage}

The results regarding the relative yield percentage of maize plant are shown in (Figs. 4 and 5) which showed that the humic acid and sulfur rates incorporated into the soil were affected significantly on relative yield from both locations Qlyasan and Kanipanka. The highest value of relative yield percentage $(108.96 \%$ and $100.05 \%)$ was observed in T5 and T8, while the lowest value of relative yield percentage $(64.95 \%$ and $78.40 \%$ ) was recorded from T15 and T13 for Qlyasan and Kanipanka locations respectively. These results are in a harmonic with those recorded by Hakanet al. (2011) and Balbaaet al. (2013) for humic acid, and the results are in agreement with the results of Dwivedi et al. (2002) for sulfur rates, they found that applying humic acid and sulfur rates affected significantly and decreased of the relative yield percentage of maize. 


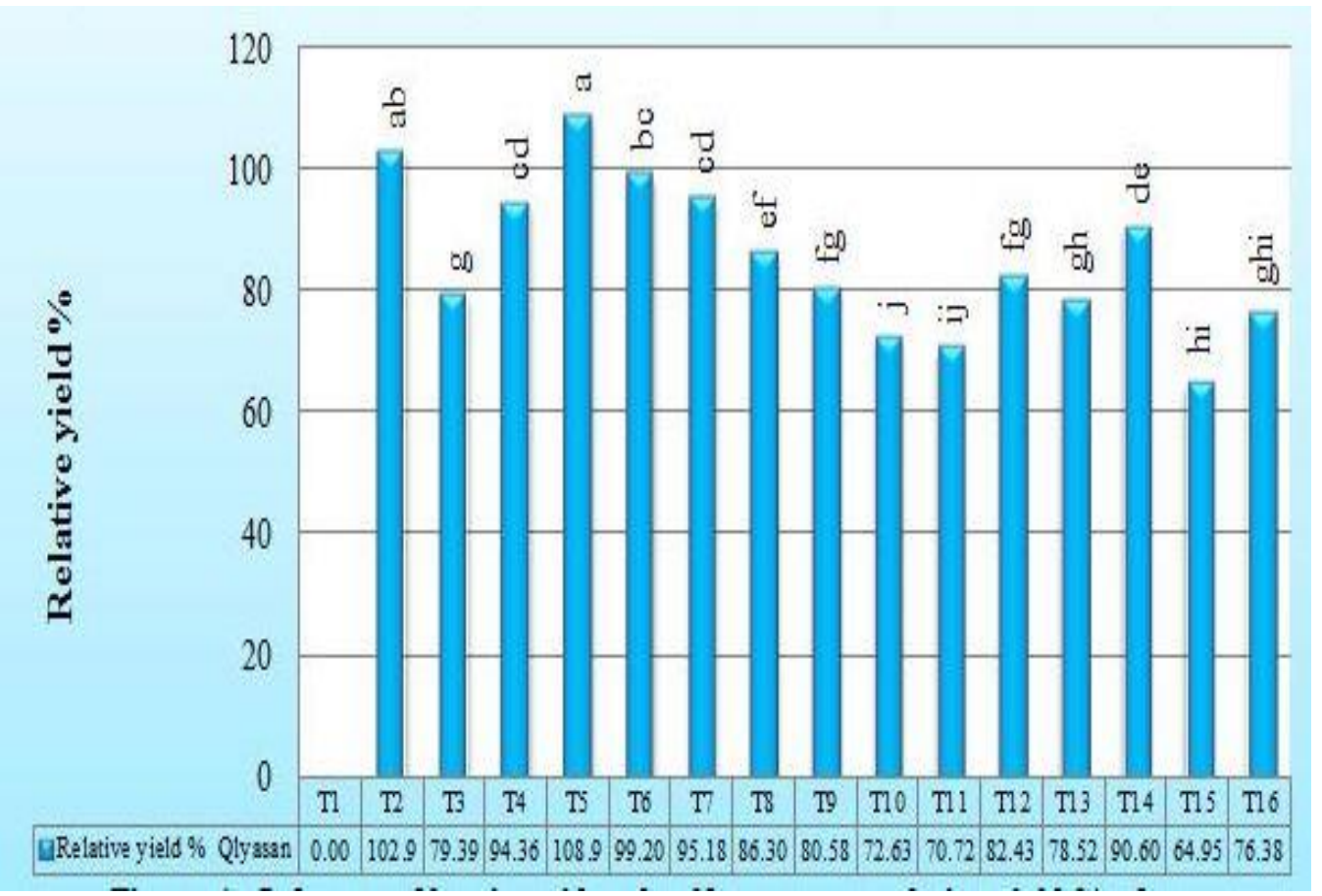

Figure 4. Influence of humic acid and sulfur on the relative yield \% of maize from Qlyasan location

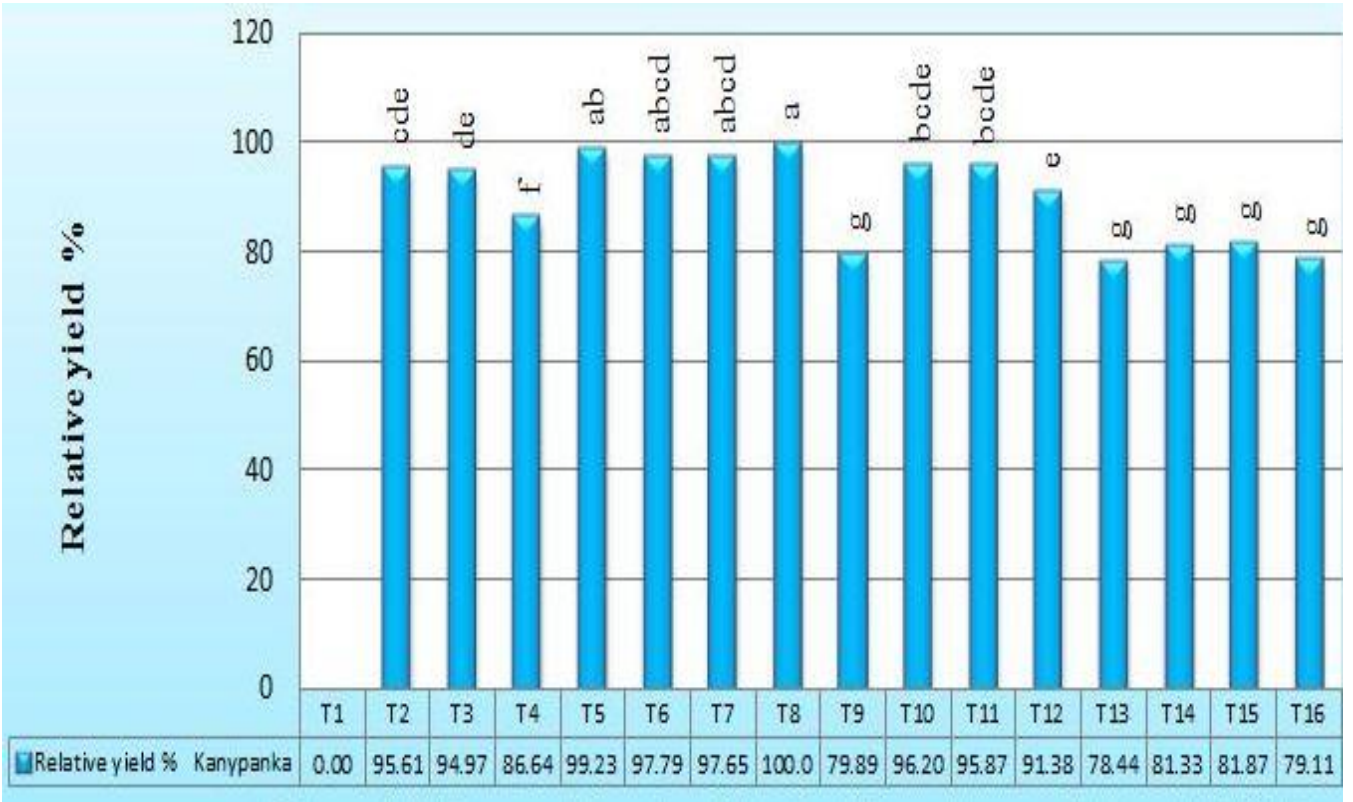

Figure 5. Influence of humic acid and sulfur on the relative yield \% of maize from Kanipanka location

\section{Discussion}

From the above results it has been observed that applying humic acid and sulfur rates in the higher levels (T16 and T15 treatments) have a significant effect on yield and yield constituents of maize in both locations, because the humic acids improve the soil 
structure (Ali et al., 2011) and through various mechanisms which were indicated to plant growth and development, enhance nutrient abundance and absorption (Berbara and Garcia, 2014). Humic acid is crucial for enhancing the abundance of nutrients through the chelation of metallic nutrients, promoting the chelation of various elements and turning them obtainable by the plant and improve the plant growth and nutrient uptake.

This process may be attributed to the distinctive structural properties of humic acid as it has so many oxygen-containing functional groups $\left(\mathrm{CO}_{2} \mathrm{H}_{2}, \mathrm{OH}\right.$, phenols, and $\mathrm{C}=\mathrm{O})$.

Humic acid is vital for modified soil physical properties. Humic acid is essential to increased plant yield through physiological effects such as the impact on the metabolism of plant cells and increasing the leaves area (Nardi et al., 2009). Increased root growth has been attributed to improved soil structure, stimulation of the soil microflora and plant growth regulator effects. For comprehensive reviews of humic acid effects on plants and because sulfur is essential in the structural and enzymatic components in plants, sulfur is a fundamental constituent of some basic amino acids that comprise proteins, and it contributes in chlorophyll synthesis. Moreover, Sulfur optimizes utilization of supplementary nutrients in plants, which are crucial for growth, development of root nodule in legumes in addition to plant protection mechanism since soil $\mathrm{pH}$ drops when sulfur is added to the soil.

Many previous studies have indicated that applying humic acid optimizes soil physical configuration, supports preserving soil moisture, raises root absorptivity of water and nutrients, promotes the production of nucleic and amino acids, promotes the action of enzymes and metabolic rate, and subsequently, optimizes yield (Dursunet al., 2002). All these pathway alterations may be attributed to humic acid since it elevates membranes absorbency and enhances the uptake of nutrients Furthermore; humic acid intensifies soil sponginess and enhances root development which in turn contributes to a larger shoot (Garcia et al., 2008). Humic acid optimizes the fresh and dry weight of shoot and root in corn (Cordeiro et al., 2011). Using sulfur fertilizers promotes growth through promoting the absorbency of soil micronutrients which eventually leads to more significant yield quantities (Fayed, 2005). Due to the significance of sulfur in root development, chlorophyll production, and metabolism, heavier fresh and dry weights of plants treated with sulfur-containing humic acid might be attributed to sulfur (Atoosa et al., 2017).

\section{Conclusion}

The results of the current work indicate that humic acid has a positive impact on the yield and its components in corn. Using humic acid may decrease the demand for other chemical and biological fertilizers to a reasonable extent. These wanted outcomes might be attributable to its impact on corn growth and physiology. Besides raising yield quantities of corn, humic acid may also contribute to realizing the objectives of agricultural sustainability. Sulfur is a central micronutrient needed for plant growth and development. Because sulfur and humic acid are involved in affecting physiological and biochemical pathways, they have to be studied thoroughly and profoundly In order to grasp better the nutritional mechanisms of sulfur about humic acid and in order to serve as a guideline for developing balanced fertilizer formulas to optimize yield quality and quantity. According to the results obtained from the present research, we guide the 
related directions to farmers in Sulaimani Governorate, Kurdistan Region - Iraq to cultivate the cv. Gloria of maize. It is necessary to implement more studies on other levels of humic substances in maize plant at different dose along with the sulfur and other methods of application for reaping higher yield and quality apart from sustaining the soil health. Evaluation of soil fertility status to other potential maize growing areas should be done to understand the deficiency situation of the nutrients

\section{REFERENCES}

[1] Abdullah, N., Muhammad, Y., Muhammad, S., Sultana, S., Ehsan, M., Nazarat, A. (2016): Maize production and nitrogen use efficiency in response to nitrogen application with and without humic acid. - Journal of Animal and Plant Science 6: 1641-1651.

[2] Ali, L. K., Nadia, A. M., El-Maghraby, T. A. (2011): Effect of P and Zn fertilization on wheat yield and nutrient uptake in calcareous soil. - Journal of Soil Science and Agriculture Engineering 2: 555-569.

[3] Alloway, B. J. (2008): Micronutrient Deficiencies in Crop Production in China. - In: Chunqin, Z., Xiaopeng, G., Rongli S., Xiaoyun, F., Fusuo Z. (eds.) Micronutrient Deficiencies in Global Crop Production. Springer, Dordrecht, pp. 127-148.

[4] Atefe, A., Ali, T. (2012): Effect of humic acid on nutrient uptake and physiological characteristic Fragaria ananassa var: Camarosa. - Journal of Biodiversity and Environmental Sciences 6(16): 77-79.

[5] Atoosa, D., Sara, H., Mohammad, A. B., Maryam, D., Mehrdad, B. (2017): The effect of sulfur-containing humic acid on yield and nutrient uptake in olive fruit. - Open Journal of Ecology 7: 279-288.

[6] Attia, A. N., El-Mosury, S. A., Mahgoub, G. M., Darwish, M. M. (2013): Effect of compost rates, humic acid treatments, and nitrogen fertilization rates on growth and yield of maize. - Journal Plant Prods 4: 509-521.

[7] Awwad, M. S., El-Hedek, K. S., Bayoumi, M. A., Eid, T. A. (2015): Effect of potassium humate application and irrigation water levels on maize yield, crop water productivity, and some soil properties. - Journal of Soil Science and Agriculture Engineering 6: 461482.

[8] Balbaa, M. G., Awad, A. M. (2013): Effect of humic acid and micronutrients foliar fertilization on yield, yield components and nutrients uptake of maize in calcareous soil. Journal Plant Production 4: 773-785.

[9] Berbara, R. L., Andrés, C. G. (2014): Humic Substances and Plant Defense Metabolism. - In: Ahmad, P., Wani, M. R. (ed.) Physiological Mechanisms and Adaptation Strategies in Plants Under Changing Environment. Springer, New York, pp. 297-319.

[10] Brady, N. C., Weil, R. R. (2002): The Nature and Properties of Soils. 13th Ed. - Prentice Hall, Upper Saddle River, NJ.

[11] Canellas, L. P., Olivares, F. L., Okorokova-Facanha, A. L., Facanha, A. R. (2002): Humic acids isolated from earthworm compost enhance root elongation, lateral root emergence and plasma membrane H-ATPase activity in maize roots. - Plant Physiology 130: 19511957.

[12] Celik, H., Ali, V. K., Baris, B. A., Murat, A. T. (2010): Effect of hummus on growth and nutrient uptake of maize under saline and calcareous soil conditions. - ZemdirbysteAgriculture Journal 97: 15-22.

[13] Chen, Y., Clapp, C. E., Magen, H. (2004b): Mechanisms of plant growth stimulation by humic substances: The role of organic-iron complexes. - Soil Science and Plant Nutrition 50: 1089-1095. 
[14] Choudhary, R., Singh, D., Singh, P., Dadarwal, R. S., Chaudhari, R. (2013): Impact of nitrogen and sulfur fertilization on yield, quality and uptake of nutrient by maize in southern Rajasthan. - Annals of Plant and Soil Research 15: 118-121.

[15] Cordeiro, F. C., Catarina, C. S., Silveira, V., De Souza, S. R. (2011): Humic acid effect on catalase activity and the generation of reactive oxygen species in corn (Zea mays). Bioscience, Biotechnology, and Biochemistry 75: 70-74.

[16] Daur, I., Ahmed, A. B. (2013): Effect of humic acid on growth and quality of maize fodder production. - Pakistan Journal Botany 45: 21-25.

[17] Dwivedi, S. K., Singh, R. S., Dwivedi, K. N. (2002): Effect of sulfur and zinc nutrition on yield and quality of maize in TypicUstropept soil of Kanpur. - Journal of the Indian Society of Soil Science 50: 70-74.

[18] Du Plessis, J. (2003): Maize Production. - Department of Agriculture, Pretoria, South Africa. www.nda.agric.za/publications.

[19] Duke, S. H., Reisenauer, H. M. (1986): Roles and Requirements of Sulfur in Plant Nutrition. - In: Tabatabai M. A. (ed.) Sulfur in Agriculture. Agronomy Monograph. American Society of Agron., Madison, WI, pp. 123-168.

[20] Dursun, A., Guvenc, I., Turan, M. (2002): Effects of different levels of humic acid on seedling growth and macro and micronutrient contents of tomato and eggplant. - Acta Agrobotanica 56: 81-88.

[21] Ebtisam, I. K., Sabreen, K., Abd El Hady, M. (2012): Improving soil properties, maize yield components grown in sandy soil under irrigation treatments and humic acid application. - Australian Journal of Basic and Applied 6: 587-593.

[22] Erdal, D., Bozkurt, M. A., Cimrin, K. M., Karaca, S., Saglam, M. (2000): Effects of humic acid and phosphorus applications on growth and phosphorus uptake of the corn plant (Zea mays L.) grown in a calcareous soil. - Turkish Journal of Agriculture and Forestry 24: 663-668.

[23] Ertani, A., Francioso, O., Tugnoli, V., Righi, V., Nardi, S. (2011): Effect of commercial lignosulfonate-humate on Zea mays L. metabolism. - Journal of Agricultural and Food Chememistry 59: 11940-11948.

[24] FAOSTAT (2013): Statistical Database of the Food and Agriculture Organization of the United Nations. - FAO, Rome, Italy. http://faostat.fao.org (accessed 4 June 2013).

[25] Farnham, D. E., Benson, G. O., Pearce, R. B. (2003): Corn Perspective and Culture. - In: White, P. J., Johnson, L. A. (eds.) Corn: Chemistry and Technology. American Association of Cerial, Chemicals, Inc., St. Paul, MN, pp. 1-33.

[26] Fayed, T. A. (2005): Effect of some organic manures and biofertilizers on Anna apple trees. Yield and fruit characteristics. - Egypt Journal of Applied Science 20: 176-191.

[27] Food and Agriculture Organization of the United Nations, Statistics Division (FAO) (2009): Maize, Rice and Wheat: Area Harvested, Production Quantity, Yield. FAO, Rome.

[28] Garcia, M. C., Francisca, S. E., Lopez, M. J., Joaquim, M. (2008): Influence of compost amendment on soil biological properties and plants. - Dynamic Soil, Dynamic Plant 1: 19.

[29] Gomaa, M. A., Radwan, F. I., Khalil, G. A., Kandil, E. E., El-Saber, M. M. (2014): Impact of humic acid application on productivity of some maize hybrids under water stress conditions. - Middle East Journal of Applied Sciences 4: 668-673.

[30] Hakan, C., VahapKatkat, A., Bulent Asık, B., Turan, M. A. (2011): Effect of foliarapplied humic acid to dry weight and mineral nutrient uptake of maize under calcareous soil conditions. - Communications in Soil Science and Plant Analysis 42: 29-38.

[31] Habtamu, A. D. (2015): Response of maize (Zea mays L.) to different levels of nitrogen and sulfur fertilizers in Chilga District, Amhara National Regional State, Ethiopia. Basic Research Journal of Soil and Environmental Science 3: 38-49. 
[32] Hogir, S. M. (2016): Interaction effect of maize genotypes and phosphate fertilization on availability of some micronutrients in calcareous soil. - Master of Science Thesis, College of Agriculture, Duhok Univ.

[33] Jones, J. B. (2003): Agronomic Hand Book: Management of Crops, Soils and Their Fertility. - CRC Press, Boca Raton, FL.

[34] Karimizarchi, M., Aminuddin, H. (2015): Effect of elemental sulphur on soil micronutrients mobility. - Journal of Agricultural Science and Food Technology 1: 3442.

[35] Karimizarchi, M., Aminuddin, H., Khanif, M. Y., Radziah, O. (2014): Elemeantal sulphur application effects on nutrient availability and sweet Maize (Zea mays L.) response in a high pH soil of Malaysia. - Malaysian Journal of Soil Science 18: 75-86.

[36] Karaca, A., Turgay, O. C., Tamer, N. (2006): Effects of a humic deposit (gyttja) on soil chemical and microbiological properties and heavy metal availability. - Biology and Fertility of Soils 42: 585-592.

[37] Khan, M. J., Muhammad, H. K., Riaz, A. K., Muhammad, T. J. (2006): Response of maize to different levels of sulfur. - Communications in Soil Science and Plant Analysis 37: $1-2$.

[38] KRG (2014): Ministry of Agriculture and Irrigation, Kurdistan Regional Government, Iraq. - https://krg-moawr.org/ku.

[39] Lalljee, B., Facknath, S. (2001): Effect of Lime on Nutrient Content of Soils, Yield and Nutrient Content of Potato and Infestation by Leaminers. - Food and Agricultural Research Council, Moka, Mauritius, pp. 139-147.

[40] Mackowiak, C. L., Grossl, P. R., Bugbee, B. G. (2001): Beneficial effects of humic acid on micronutrient availability to wheat. - Soil Science Society of America Journal 56: 1744-1750.

[41] Makary, B. S. (2002): Effect of some organic and inorganic fertilizers with sulfur element on the yield of corn and its influence on some soil properties. - Journal of Agricultural Science 27: 1301-1313.

[42] Muhammad, I. K., Mohammad, Q., Muhammad, S., Hamayun, K., Muhammad, A., Muhammad, R. (2015): Response of maize crop to different levels of humic acid. - Life Sciences International Journal 9: 3116-3120.

[43] Nader, R. H., Nadia, M. H. (2011): Effects of elemental sulphur and partial substitution of $\mathrm{N}$-mineral fertilizer by organic amendments on some properties of slight saline soils. Journal of Applied Sciences Research 7: 2102-2111.

[44] Nardi, S., Carletti, P., Pizzeghello, D., Muscolo, A. (2009): Biological Activities of Humic Substances. - In: Senesi, N., Xing, B., Huang, P. M. (eds.) Biophysico-Chemical Processes Involving Natural Nonliving Organic Matter in Environmental Systems. Wiley, Hoboken, pp. 305-339.

[45] Navigeh, R., Mehrdad, Y., Davood, H. P. (2012): Effect of drought stress and potassium humate application on grain yield-related traits of corn (cv. 604). - Journal of Food, Agriculture and Environment 10: 580-584.

[46] Pal, D. K., Sasog, G. S., Vadivelu, S., Ahiya, R. L., Bhattacharyya, T. (2000): Secondary Calcium Carbonate in Soils in Arid and Semi-Arid Regions of India. - In: Lal, R., Kimble, J. M., Eswaran, H., Stewart, B. A. (eds.) Global Climatic Change and Pedogenic Carbonates. Lewis Publishers, CRS Press, New York, pp. 149-185.

[47] Pasricha, N. S., Bansal, S. K., Golakiya, B. A. (2001): Balanced Nutrition of Groundnut and Other Field Crops Grown in Calcareous Soils of India. - Potash Research Institute of India, Gurugram, pp. 5-19.

[48] Rheinheimer, D. S., Rasche, J. W. A., Osorio, Filho, B. D., Silva, L. S. (2007): Responses to sulphur application and recuperation in greenhouse crops in soils with different clay and organic matter content. - Ciência Rural (CR) 37: 363-371. 
[49] Salimpour, S., Khavazi, K., Nadian, H., Besharati, H., Miransari, M. (2010): Enhancing phosphorous availability to canola (Brassica napus L.) using $\mathrm{P}$ solubilizing and sulfur oxidizing bacteria. - Australian Journal of Crop Science 4: 330-334.

[50] Scherer, H. W. (2001): Sulphur in crop production - invited paper. - European Journal of Agronomy 14: 81-111.

[51] Shah, S. T., Zamir, S. I., Waseem, M., Ali, A., Tahir, M., Khalid, B. W. (2009): Growth and yield response of maize (Zea mays L.) to organic and inorganic sources of nitrogen. Pakistan Journal of Life and Social Science 7: 108-111.

[52] Sharif, M., Khattak, R. A., Sarir, M. S. (2002): Effect of different levels of lignitic coal derived humic acid on growth of maize plants. - Communications in Soil Science and Plant Analysis 33: 3567-3580.

[53] Sharma, R. C., Smith, E. L., McNew, R. W. (1987): Stability of harvest index and grain yield in winter wheat. - Crop Science 27: 104-107.

[54] Sikandar, A., Ali, M., Amin, M., Bibi, S., Arif, M. (2007): Effect of plant population on maize hybrids. - Journal of Agricultural and Biological Science 2: 13-20.

[55] Singh, R. P., Agrawal, M. (2010): Effect of different sewage sludge applications on growth and yield of Vigna radiata L. field crop: metal uptake by plant. - Ecological Engineering 36: 969-972.

[56] Srinivasrao, C., Masood, A., Venkateshwaralu, S., Rupa, T. R., Singh, K. K., Sumanta Kundu, S., Prasad, J. V. (2010): Direct and residual effects of integrated sulfur fertilization in maize (Zea mays) - chickpea (Cicer arietinum) cropping system on typic ustochrept. - Indian Journal of Agronomy 55: 259-263.

[57] Stevenson, F. J. (1994): Humus Chemistry: Genesis, Composition, Reactions. - John Wiley \& Sons, New York.

[58] Szulc, P., Jan, B., Zajac, M. R. (2012): The effect of soil supplementation with nitrogen and elemental sulfur on chlorophyll content and grain yield of maize (Zea mays L.). Polish Journal of Environmental Studies 99: 247-254.

[59] Tisdale, S. L., Nelson, W. L., Beaton, J. D., Havlin, J. L. (1995): Soil Fertility and Fertilizer. 5th Ed. - Prentice-Hall of India, New Delhi.

[60] Turan, M. A., Asik, B. B., Katkat, A. V., Celik, H. (2011): The effects of soil-applied humic substances to the dry weight and mineral nutrient uptake of maize plants under soil salinity conditions. - Notulae Botanicae Horti Agrobotanici Cluj-Napoca 39: 171-177.

[61] Turkmen, O., Dursun, A., Turan, M., Erdinc, C. (2004): Calcium and humic acid affect seed germination, growth, and nutrient content of tomato (Lycopersicon esculentum L.) seedlings under saline soil conditions. - Acta Agriculturae Scandinavica, Section B- Soil and Plant Science 54: 168-174.

[62] Ulukan, H. (2008): Humic acid application into field crops cultivation. - KS University Journal Science Engineering 11: 119-128. 